\title{
Analisis Rasio Luas Kolam Tampung Terhadap Luas Daerah Terbangun dalam Upaya Pengendalian Banjir di Wilayah Drainase Selatan Kota Balikpapan
}

\author{
Ratio Analysis of Storage Pond Area to the Built Area as Flood \\ Control Effort in Balikpapan Southern Drainage Area
}

\author{
Rossana Margaret Kadar Yanti ${ }^{1, a)}$ \& Besse Nadia Irawan ${ }^{2, b)}$ \\ ${ }^{1)}$ Dosen Teknik Sipil, Institut Teknologi Kalimantan (ITK), Balikpapan. \\ ${ }^{2)}$ Mahasiswa Teknik Sipil, Institut Teknologi Kalimantan (ITK), Balikpapan.
}

Koresponden : ${ }^{a)}$ rossa.margareth@ lecturer.itk.ac.id \& ${ }^{b}$ 07161014@student.itk.ac.id

\begin{abstract}
ABSTRAK
Kota Balikpapan mengalami peningkatan penduduk selaras dengan permintaan akan tempat tinggal, hal ini menyebabkan peningkatan debit limpasan pada saluran drainase kota akibat perubahan tutupan lahan. Implementasi prinsip Zero Delta Q Policy sesuai peraturan pemerintah No.26 Tahun 2008 kemudian dilakukan agar dapat mereduksi besaran debit limpasan dari perumahan menuju saluran drainase kota, dalam mencegah peningkatan debit limpasan dan banjir. Prinsip ini dicek penerapannya pada perumahan Jamrud Residence, Neo Batakan Permai, dan GBR 6 di wilayah drainase selatan. Metode yang dilakukan yaitu analisis curah hujan maksimum, debit limpasan saat kondisi kawasan belum terbangun $\left(\mathrm{Q}_{\text {awal }}\right)$ dan kawasan terbangun $\left(\mathrm{Q}_{\text {terbangun }}\right)$, delta $\mathrm{Q}$ (selisih antara $\mathrm{Q}_{\text {awal }}$ dengan $\mathrm{Q}_{\text {terbangun}}$ ), hidrograf kolam tampung, rasio luasan kolam tampung terhadap kawasan terbangun, dan persamaan regresi linier. Qawal pada perumahan Jamrud Residence, Neo Batakan Permai, dan GBR 6 sebesar 0,3485 m³/detik, 4,4017 $\mathrm{m}^{3} /$ detik, dan $0,4077 \mathrm{~m}^{3} /$ detik. Qterbangun pada perumahan Jamrud Residence, Neo Batakan Permai, dan GBR 6 adalah berturut-turut sebesar 1,0043 $\mathrm{m}^{3} /$ detik, 15,0329 $\mathrm{m}^{3} /$ detik, dan 0,9166 $\mathrm{m}^{3} /$ detik. Rasio luasan kolam tampung pada perumahan Jamrud Residence, Neo Batakan Permai, dan GBR 6 adalah masing-masing berurutan sebesar 8,267\%, 9,891\%, dan $10,256 \%$. Model regresi linier luas kolam tampung terhadap luas kawasan adalah $\mathrm{Y}=$ $0,145 \mathrm{X}_{1}-332,28$ dengan koefisien determinasi $\left(\mathrm{R}^{2}\right)$ sebesar $0,999 \approx 1$.
\end{abstract}

Kata Kunci : debit limpasan, kolam tampungan, zero delta q policy, manajemen infrastruktur, perencanaan

\section{PENDAHULUAN}

Kota Balikpapan mengalami pertambahan penduduk setiap tahunnya, berdasarkan data yang didapatkan dari Badan Pusat Statistik (BPS, 2019) pada tahun 2018 tercatat jumlah penduduk kota Balikpapan yaitu sebanyak 645,272 ribu jiwa. Peningkatan jumlah penduduk yang begitu pesat ini berbanding lurus dengan peningkatan permintaan akan tempat tinggal. Beberapa contoh perumahan yang sedang dalam tahap pembangunan antara lain seperti perumahan Jamrud Residence (Rahayu, 2017; Jaya, 2019), Neo Batakan Permai, dan GBR 6 (Nusantara, 2020) yang berada di wilayah drainase selatan. Pembangunan perumahanperumahan ini dilakukan di lahan terbuka yang kemudian beralih menjadi suatu kawasan perumahan. Peralihan fungsi tersebut mempengaruhi proses infiltrasi air hujan kedalam tanah akibat berubahnya tutupan lahan dan menyebabkan meningkatnya angka koefisien pengaliran. 
Proses peningkatan koefisien pengaliran ini menyebabkan peningkatan debit limpasan. Peningkatan debit limpasan pada saluran drainase kota dapat menyebabkan terjadinya peningkatan elevasi muka air sebagai salah satu faktor terjadinya luapan.

Kawasan perumahan beserta seluruh infrastruktur pendukung yang ada di dalamnya perlu dipandang sebagai aset yang harus sesuai dengan prinsip tetap dapat terjaga kelangsungannya agar dapat memberi manfaat secara luas (Suprayitno \& Soemitro, 2018). Dalam tinjauan pengembangan perumahan di Kota Balikpapan, pengelolaan terhadap aset tersebut berpegang pada konsep perencanaan dan perancangan, salah satunya adalah bebas banjir dan genangan. Upaya yang dapat dilakukan untuk mengatasi peningkatan debit limpasan dari perumahan salah satunya dengan melakukan suatu kajian dengan menerapkan prinsip Zero Delta $Q$ Policy. Prinsip Zero Delta Q Policy merupakan istilah dalam Peraturan Pemerintah No. 26 Tahun 2008 tentang Rencana Tata Ruang Wilayah Nasional, dalam Ayat 1 Pasal 106 (c) yang menyebutkan "penerapan prinsip Zero Delta $Q$ policy terhadap setiap kegiatan budidaya terbangun yang diajukan izinnya". Prinsip ini bertujuan untuk mereduksi besaran debit limpasan yang masuk ke dalam saluran agar tidak meningkatkan beban pada saluran drainase kota. Analisis selisih debit limpasan yang disebut Zero Delta $Q$ Policy ini perlu dilakukan sebagai dasar dalam menentukan besar debit yang akan disalurkan ke saluran outlet sesuai kondisi kawasan saat belum terbangun. Untuk menampung selisih debit akibat pembangunan, maka dapat direncanakan kolam tampung sebagai salah satu upaya untuk mengontrol debit yang keluar dari kawasan (Maulana, Suprayitno, \& Soemitro, 2019). Implementasi prinsip Zero Delta Q Policy dilakukan dengan analisis curah hujan maksimum pada data hujan 15 tahun, debit limpasan saat kondisi kawasan belum terbangun $\left(\mathrm{Q}_{\text {awal }}\right)$ dan kawasan terbangun $\left(\mathrm{Q}_{\text {terbangun }}\right)$, analisis Delta $\mathrm{Q}$ (selisih $\mathrm{Q}_{\text {awal }}$ dengan $\mathrm{Q}_{\text {terbangun}}$ ), hidrograf kolam tampung berupa kolam detensi dan analisis rasio luasan kolam tampung terhadap kawasan terbangun serta pemodelan persamaan regresi.

Penelitian ini bertujuan untuk menganalisis perubahan debit limpasan pada kawasan yang mengalami alih fungsi lahan dari lahan resapan menjadi perumahan yang semi kedap. Hasil dari penelitian ini diharapkan dapat memberi masukan bagi pemangku kebijakan dalam menentukan batasan ijin pengembangan wilayah agar tidak memberikan beban berlebih terutama bagi badan penerima air yang telah ada.

\section{METODA PENELITIAN}

Penelitian ini dilaksanakan dalam 4 tahap utama. Tahapan yang dilakukan dalam melakukan analisis ini adalah sebagai berikut:

1. Identifikasi Masalah

Identifikasi masalah dilakukan dengan mengkaji kondisi yang terjadi di lingkungan masyarakat yaitu debit limpasan pada saat kondisi kawasan belum terbangun $\left(\mathrm{Q}_{\text {awal }}\right)$ dan kondisi kawasan telah terbangun ( $\left.\mathrm{Q}_{\text {terbangun }}\right)$, implementasi prinsip Zero Delta Q Policy berupa rasio luasan kolam tampung, serta pemodelan persamaan regresi linier luas kolam tampung terhadap luas kawasan.

2. Studi Literatur

Studi literatur dilakukan untuk mendapatkan referensi berupa kegiatan perencanaan terdahulu dengan konsep dan tujuan yang sama agar dapat dijadikan pedoman dalam menentukan langkah kerja yang tepat. Studi literatur juga dilakukan dalam penentuan metode pengolahan data, tahap-tahap pengolahan data, dan hasil yang diinginkan

3. Pengumpulan Data

a. Data site plan perumahan, digunakan untuk menentukan luasan lahan yang digunakan untuk tiap-tiap perumahan serta tata guna lahan sebagai penentu koefisien pengaliran. Data site plan yang digunakan didapatkan melalui PT. Bima Sakti Rahayu untuk perumahan Jamrud Residence, PT. Keysya Maju Jaya untuk perumahan Neo Batakan Permai, dan PT. Kalimantan Pelita Nusantara untuk perumahan GBR 6 
b. Data Hidrologi, berupa data curah hujan maksimum harian selama 15 tahun.

4. Analisis Hidrologi

a. Pengumpulan data curah hujan maksimum tahunan

b. Menganalisis parameter statistik dengan menghitung nilai rata-rata, standar deviasi, koefisien variasi, koefisien kemencengan dan koefisien kurtosis menggunakan persamaan distribusi hujan, analisis kecocokan, analisis curah hujan rencana dan analisis debit banjir.

c. Menganalisis terhadap uji kecocokan dengan Metode Chi-kuadrat dan Metode Smirnov-Kolmogorov.

d. Menganalisis curah hujan pada periode ulang tertentu dengan Metode Distribusi Normal, Distribusi Log Normal,

e. Distribusi Log Pearson Tipe III, Distribusi Gumbel.

f. Menganalisis koefisien aliran menganalisis waktu konsentrasi menggunakan Persamaan Kerby dan Kirpich.

g. Menganalisis intensitas curah hujan dengan Metode Mononobe.

h. Menganalisis banjir rencana dengan Metode Rasional.

i. Menganalisis zero delta $Q$.

5. Analisis hidrograf kolam tampung pada masing-masing perumahan.

6. Analisis rasio luasan dan pemodelan persamaan regresi linier

Analisis rasio luasan dilakukan untuk mengetahui rasio perbandingan dari ketersediaan kolam tampungan terhadap luasan kawasan terbangun. Setelah mendapat rasio luasan kolam tampungan, luasan kolam tampungan dari masing-masing rasio tersebut dianalisis dengan pemodelan persamaan regresi linier sederhana.

\section{ANALISIS PENELITIAN}

\section{Lokasi Penelitian}

Lokasi penelitian dalam analisis terhadap implementasi prinsip zero delta $Q$ policy ini dilakukan pada perumahan yang terletak di wilayah drainase selatan yaitu Perumahan Jamrud Residence (Gambar 1), Neo Batakan Permai (Gambar 2), dan GBR 6 (Gambar 3).

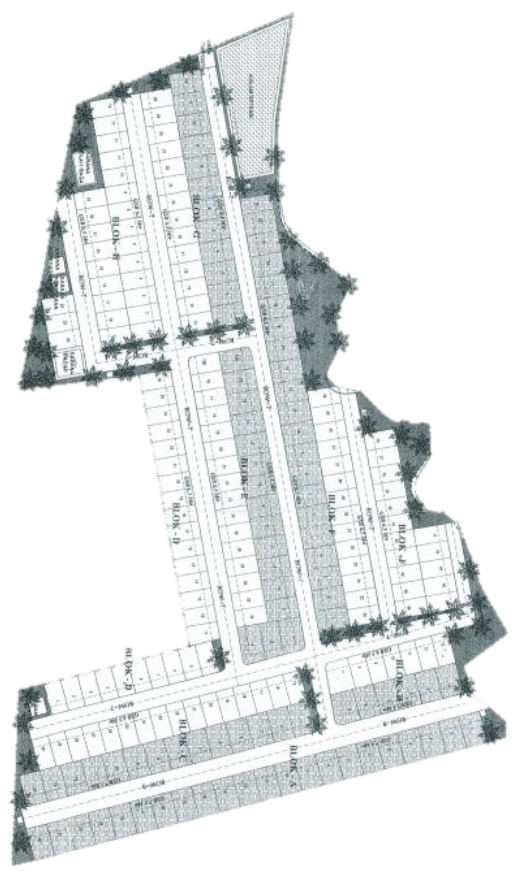


Gambar 1. Site Plan Perumahan Jamrud Residence

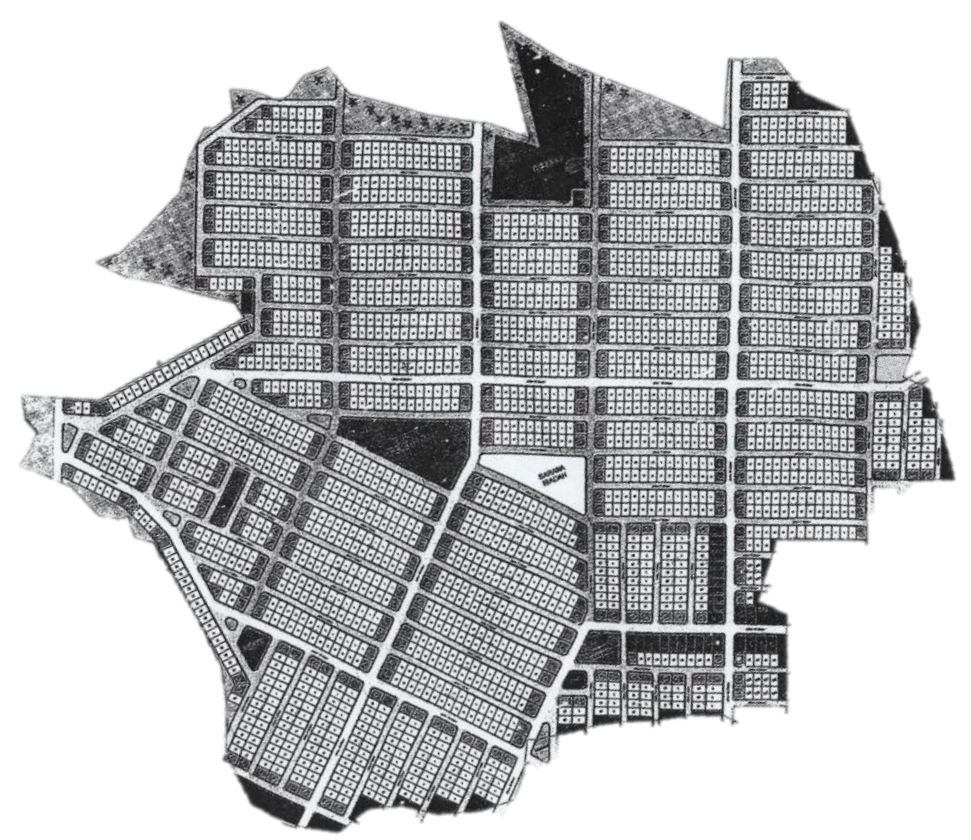

Gambar 2. Site Plan Perumahan Neo Batakan Permai

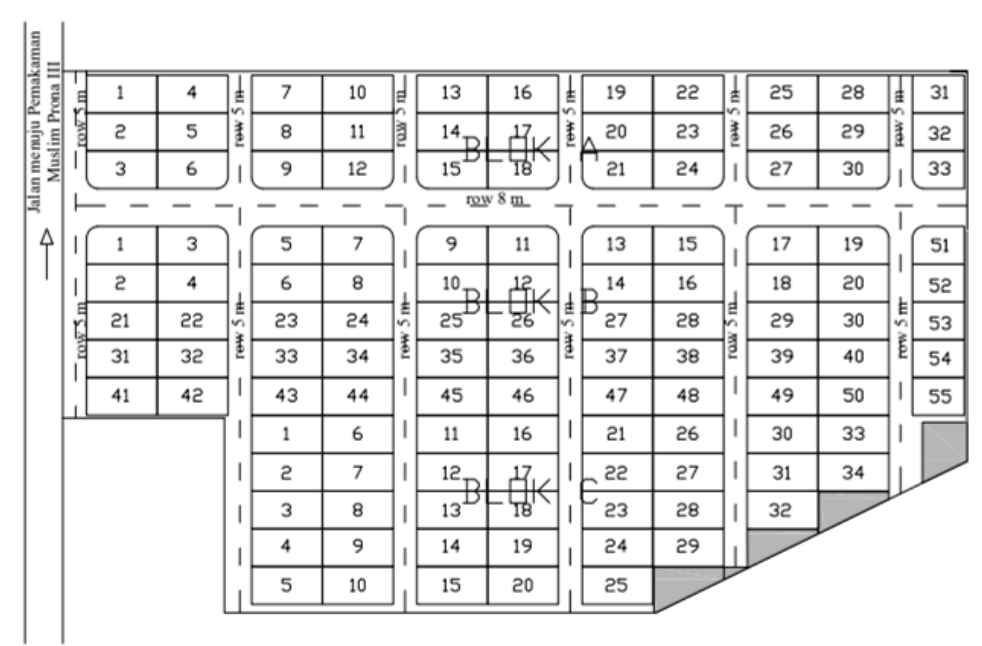

Gambar 3. Site Plan Perumahan GBR 6

\section{Analisis Hidrologi}

Analisis hidrologi dilakukan dengan menggunakan data hujan harian maksimum selama 15 tahun yang didapatkan dari Badan Meteorologi, Klimatologi dan Geofisika (BMKG) terhitung mulai tahun 2005 hingga 2019. Data hujan kemudian dianalisis hingga didapatkan debit limpasan dari masing-masing perumahan sebagai berikut:

\section{Analisis Hujan Rencana}

Data curah hujan yang didapatkan dari Badan Meteorologi, Klimatologi dan Geofisika (BMKG) disajikan pada Tabel 1 sebagai berikut. 
Tabel 1. Data Curah Hujan Harian Maksimum $\left(X_{i}\right)$

\begin{tabular}{cccc}
\hline No. & Tahun & Tanggal & $\boldsymbol{X}_{\boldsymbol{i}}$ \\
\cline { 4 - 4 } 1 & 2017 & $4 / 6 / 2017$ & $\mathbf{m m}$ \\
2 & 2019 & $13 / 07 / 2019$ & 165,8 \\
3 & 2008 & $20 / 06 / 2008$ & 164,8 \\
4 & 2018 & $1 / 7 / 2018$ & 161,4 \\
5 & 2007 & $1 / 9 / 2007$ & 154,2 \\
6 & 2012 & $26 / 06 / 2006$ & 148,0 \\
7 & 2006 & $1 / 7 / 2009$ & 133,4 \\
8 & 2009 & $25 / 05 / 2012$ & 132,0 \\
9 & 2010 & $21 / 02 / 2010$ & 119,7 \\
10 & 2011 & $29 / 06 / 2011$ & 119,6 \\
11 & 2015 & $12 / 6 / 2015$ & 108,1 \\
12 & 2005 & $21 / 11 / 2005$ & 107,5 \\
13 & 2014 & $14 / 03 / 2014$ & 102,5 \\
14 & 2013 & $8 / 8 / 2013$ & 94,0 \\
15 & 2016 & $4 / 12 / 2016$ & 75,6 \\
\hline sumber $:$ BM KG, 2020 & &
\end{tabular}

Dimana

$X_{i}=$ Curah hujan harian maksimum

Berdasarkan Tabel 1, data hujan selama 15 tahun telah diurutkan berdasarkan data nilai terbesar hingga nilai terkecil. Perhitungan yang akan dilakukan dengan data tersebut adalah perhitungan parameter statistik sesuai Suripin (2014) dengan persamaan sebagai berikut:

a. Nilai Rata-rata (Mean)

$$
\bar{X}=\frac{1}{n} \sum_{i=1}^{n} X_{i}
$$

Dimana

$$
\begin{array}{ll}
\bar{X} & =\text { Tinggi hujan rata-rata selama } \mathrm{n} \text { tahun }(\mathrm{mm}) \\
X_{i} & =\text { Curah hujan harian maksimum }(\mathrm{mm}) \\
\mathrm{n} & =\text { Jumlah data hujan }
\end{array}
$$

b. Standar Deviasi (Standard of deviation)

$$
s=\sqrt{\frac{\sum\left(X_{i}-\bar{X}\right)^{2}}{n-1}}
$$

Dimana

$$
\begin{array}{ll}
\mathrm{s} & =\text { Simpangan Baku atau Standar Deviasi }(\mathrm{mm}) \\
\bar{X} & =\text { Tinggi hujan rata-rata selama } \mathrm{n} \text { tahun }(\mathrm{mm}) \\
X_{i} & =\text { Curah hujan harian maksimum }(\mathrm{mm}) \\
\mathrm{n} & =\text { Jumlah data hujan }
\end{array}
$$

c. Koefisien Kemencengan (Skewness)

$$
C s=\frac{n \cdot \sum\left(X_{i}-\bar{X}\right)^{3}}{(n-1) \cdot(n-2) \cdot s^{3}}
$$

Dimana

$$
\text { Cs = Koefisien kemencengan }
$$




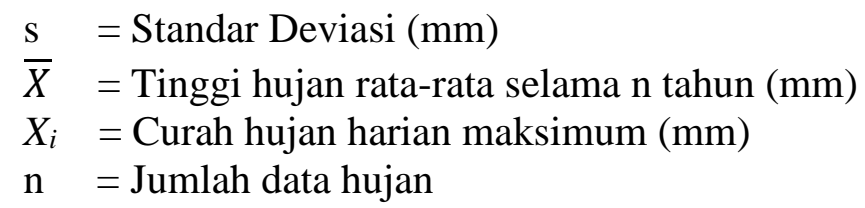

d. Koefisien Ketajaman (Curtosis)

$$
C k=\frac{n^{2} \cdot \Sigma\left(X_{i}-\bar{X}\right)^{4}}{(n-1) \cdot(n-2) \cdot(n-3) \cdot s^{4}}
$$

Dimana

$$
\begin{array}{ll}
\mathrm{Ck} & =\text { Koefisien kemencengan } \\
\mathrm{s} & =\text { Standar Deviasi }(\mathrm{mm}) \\
\bar{X} & =\text { Tinggi hujan rata-rata selama } \mathrm{n} \text { tahun }(\mathrm{mm}) \\
X_{i} & =\text { Curah hujan harian maksimum }(\mathrm{mm}) \\
\mathrm{n} & =\text { Jumlah data hujan }
\end{array}
$$

Nilai Cs dan Ck kemudian digunakan dalam penentuan jenis distribusi peluang yang akan digunakan dengan diuji terhadap syarat distribusi (Suripin, 2014) yang ditunjukkan oleh Tabel 2 sebagai berikut.

Tabel 2. Hasil Uji Statistik

\begin{tabular}{ccccc}
\hline No & Jenis Distribusi & Syarat & Hasil Analisis & Keterangan \\
\hline \multirow{2}{*}{$\mathbf{1}$} & Normal & $\mathrm{Cs} \approx 0$ & & Memenuhi \\
& & $\mathrm{Ck} \approx 3$ & & $\begin{array}{c}\text { Memenuhi } \\
\text { Tidak Memenuhi }\end{array}$ \\
$\mathbf{2}$ & Log Normal & $\mathrm{Cs}=3$ & & Tidak Memenuhi \\
& & $\mathrm{Ck}=3 \mathrm{xCv}$ & $\mathrm{Cs}=0,22$ & Tidak Memenuhi \\
$\mathbf{3}$ & Gumbel & $\mathrm{Cs} \approx 1,1396$ & $\mathrm{Ck}=3,17$ & Tidak Memenuhi \\
& & $\mathrm{Ck} \approx 5,4002$ & & Memenuhi \\
4 & Log Pearson Type III & Flexibel & & Memenuhi \\
\hline
\end{tabular}

Berdasarkan Tabel 2, nilai Cs dan $\mathrm{Ck}$ yang memenuhi syarat adalah dari Distribusi Normal dan Log Pearson Type III sesuai SNI 2415-2016 mengenai "Tata Cara Perhitungan Debit Banjir Rencana", sehingga jenis Distribusi Normal dan Log Pearson Type III inilah yang kemudian akan digunakan dalam tahap uji kecocokan.

\section{Uji Kecocokan}

Pengujian terhadap uji kecocokan dilakukan dalam dua tahap yaitu menggunakan Persamaan Chi-kuadrat dan Smirnov-Kolmogorov (Suripin, 2004).

a. Metode Chi-Kuadrat

Metode ini dilakukan untuk mengetahui distribusi statistik sampel data yang digunakan dalam analisis telah menggunakan persamaan distribusi yang sesuai atau belum. Tes kesesuaian dilakukan dengan menggunakan persamaan sebagai berikut.

$$
\chi_{h}^{2}=\sum_{i=1}^{G} \frac{\left(O_{i}-E_{i}\right)^{2}}{E_{i}}
$$

Dimana

$$
\begin{array}{ll}
\chi_{h}^{2} & =\text { Parameter chi-kuadrat terhitung } \\
\mathrm{G} & =\text { Jumlah sub kelompok } \\
\mathrm{O}_{\mathrm{i}} & =\text { Jumlah nilai pengamatan pada sub kelompok ke-i } \\
\mathrm{E}_{\mathrm{i}} & =\text { Jumlah nilai teoritis pada sub kelompok ke-i }
\end{array}
$$


$\mathrm{Dk}=\mathrm{G}-\mathrm{R}-1$

Dimana

$\mathrm{Dk}=$ Derajat kebebasan

$\mathrm{G} \quad=$ Jumlah seluruh subkelompok

$\mathrm{R}=$ Nilai untuk metode distribusi normal dan binomial, $\mathrm{R}=2$

b. Metode Smirnov-Kolmogorov

Metode ini memiliki sebutan lain yakni uji kecocokan non parametrik karena fungsi distribusi tertentu tidak digunakan dalam pengujian. Langkah-langkah pengujian dilakukan sebagai berikut.

$\mathrm{d}_{\max }=\operatorname{Maksimum}\left(\mathrm{P}\left(\mathrm{X}_{\mathrm{n}}\right)-\mathrm{P}^{\prime}\left(\mathrm{X}_{\mathrm{n}}\right)\right)$

Dimana

$\mathrm{d}_{\max }=$ Selisih terbesar antara peluang pengamatan dan peluang teoritis

$\mathrm{P}\left(\mathrm{X}_{\mathrm{n}}\right)=$ Nilai peluang pengamatan data ke- $\mathrm{n}$

$\mathrm{P}^{\prime}\left(\mathrm{X}_{\mathrm{n}}\right)=$ Nilai peluang teoritis data ke-n

$\mathrm{d}_{\mathrm{o}} \quad=$ Nilai kritis berdasarkan derajat kepercayaan $(0,3400)$ berikut.

Dari dua tahap uji kecocokan yang telah dilakukan, didapatkan hasil pada Tabel 3 sebagai

Tabel 3. Kesimpulan Uji Kecocokan

\begin{tabular}{lllllclcl}
\hline \multirow{2}{*}{$\begin{array}{c}\text { Jenis distribusi } \\
\text { probabilitas }\end{array}$} & \multicolumn{3}{c}{ Chi-Kuadrat } & \multicolumn{2}{c}{ SMIRNOV-KOLMOGROV } \\
\cline { 2 - 7 } Normal & $X_{h}^{2}$ & $<$ & $\mathrm{X}^{2}$ & Ket. & $\mathrm{d}_{\max }$ & $<$ & $\mathrm{d}_{\mathrm{o}}$ & Ket. \\
Log pears on tipe III & 1,333 & $<$ & 5,991 & Diterima & 0,0611 & $<0,3400$ & Diterima \\
\hline
\end{tabular}

Dimana :

$\chi_{h}^{2} \quad=$ Parameter chi-kuadrat terhitung

$\mathrm{X}^{2}=$ Nilai kritis uji Chi-Kuadrat dengan derajat kebebasan $=2$ dan $\alpha=5 \%(5,991)$

$\mathrm{d}_{\max }=$ Selisih terbesar antara peluang pengamatan dan peluang teoritis

$\mathrm{d}_{\mathrm{o}} \quad=$ Nilai kritis berdasarkan derajat kepercayaan $(0,3400)$

Berdasarkan Tabel 3, kedua distribusi ini memenuhi persyaratan sehingga dalam tahap perhitungan curah hujan periode ulang, kedua distribusi ini dapat digunakan.

Perhitungan Curah Hujan Periode Ulang

Periode ulang yang akan dianalisis dalam perhitungan ini adalah periode ulang 5 tahun karena merupakan kawasan pemukiman dan saluran yang menuju kolam tampung merupakan saluran sekunder. Hasil perhitungan curah hujan periode ulang (Suripin, 2014) adalah sebagai berikut :

a. Curah hujan Distribusi Normal

Data yang dibutuhkan antara lain :

$\bar{X}$, nilai rata-rata $(\mathrm{mm})=132,307 \mathrm{~mm}$

Periode Ulang (tahun) $=5$ Tahun

$\mathrm{s}$, standar deviasi $\quad=32,907$

$\mathrm{K}_{\mathrm{T}}$, faktor frekuensi $=0,84$

Penyelesaian : 


$$
\begin{aligned}
\mathrm{X}_{5} & =\bar{X}+K_{T} \times s \\
\mathrm{X}_{5} & =132,307+0,84 \times 32,907 \\
\mathrm{X}_{5} & =159,948 \mathrm{~mm}
\end{aligned}
$$

\section{b. Curah hujan Distribusi Log Pearson III}

Data yang dibutuhkan antara lain:

$\log \bar{X}$, nilai rata-rata $(\mathrm{mm})=2,108 \mathrm{~mm}$

Periode Ulang (tahun) $=5$ Tahun

$\operatorname{logSd}$, standar deviasi $\quad=0,111$

$\mathrm{K}_{\mathrm{T}}$, faktor frekuensi $\quad=0,855+\left(\frac{(-0,33)-(-0,4)}{(-0.2)-(-0,4)}\right) \times(0,850-0,855)=0,853$

Penyelesaian :

$$
\begin{array}{ll}
\log \mathrm{X}_{5} & =\log \bar{X}+K_{T} \times s \log X \\
\log \mathrm{X}_{5} & =2,108+0,853 \times 0,111 \\
\log \mathrm{X}_{5} & =2,204 \mathrm{~mm} \\
\mathrm{X}_{5} & =159,857 \mathrm{~mm}
\end{array}
$$

Dari hasil perhitungan curah hujan dengan menggunakan kedua distribusi tersebut, nilai yang digunakan adalah hasil perhitungan curah hujan dengan Distribusi Normal sebesar 159,948 mm karena merupakan nilai maksimum di antara kedua distribusi yang digunakan.

\section{$\underline{\text { Koefisien Pengaliran }}$}

Koefisien pengaliran memiliki parameter nilai sesuai klasifikasi yang dipengaruhi oleh kondisi permukaan tanah, kemiringan, jenis tanah, lamanya hujan di daerah pengaliran menurut Suripin (2004). Adapun hasil analisis tutupan lahan pada perumahan disajikan pada Tabel 4. sebagai berikut.

Tabel 4. Koefisien Pengaliran Tiap Perumahan

\begin{tabular}{ccccc}
\hline \multirow{2}{*}{ Kondisi } & \multirow{2}{*}{ Kategori } & \multicolumn{3}{c}{ Perumahan } \\
\cline { 3 - 5 } & Jahan hijau $\left(\mathrm{m}^{2}\right)$ & 31.450 & 424.633 & 19.500 \\
Kawasan belum & $\mathrm{C}$ & 0,4 & 0,5 & 0,5 \\
\hline \multirow{2}{*}{ terbangun } & Bangunan $\left(\mathrm{m}^{2}\right)$ & 19.671 & 264.438 & 14.384 \\
& $\mathrm{C}$ & 0,75 & 0,6 & 0,6 \\
Kawas an telah terbangun & Jalan $\left(\mathrm{m}^{2}\right)$ & 4.526 & 91.741 & 4.288 \\
& $\mathrm{C}$ & 0,95 & 0,95 & 0,95 \\
& $\mathrm{RTH}\left(\mathrm{m}^{2}\right)$ & 7.253 & 68.454 & 828 \\
& $\mathrm{C}$ & 0,25 & 0,25 & 0,25 \\
\hline
\end{tabular}

Berdasarkan Tabel 4, angka koefisien pengaliran pada kawasan belum tebangun untuk hutan adalah 0,4 pada perumahan Jamrud Residence karena merupakan hutan dengan tipe daerah aliran yang datar dan 0,5 pada perumahan Neo Batakan Permai dan GBR 6 karena merupakan hutan dengan tipe daerah aliran yang bergelombang berdasarkan kondisi tutupan lahan. Koefisien pengaliran pada kawasan telah terbangun untuk bangunan pada perumahan Jamrud Residence sebesar 0,75 karena merupakan perumahan multi unit tergabung sedangkan pada perumahan Neo Batakan Permai dan GBR 6 sebesar 0,6 karena merupakan perumahan multi unit terpisah. Pada kondisi dengan tutupan lahan yang beragam, maka dilakukan perhitungan nilai $\mathrm{C}$ secara keseluruhan atau $\mathrm{C}$ gabungan dengan persamaan (Suripin, 2014) sebagai berikut : 


$$
\mathrm{C}=\frac{\sum_{i=1}^{n} C_{i} A_{i}}{\sum_{i=1}^{n} A_{i}}
$$

Dimana

$\mathrm{C}=$ Koefisien pengaliran lahan

A = Luas lahan $\left(\mathrm{m}^{2}\right)$

Dengan menggunakan persamaan 10, maka didapatkan hasil perhitungan $\mathrm{C}_{\text {gabungan }}$ yang disajikan pada Tabel 5. Berdasarkan Tabel 5, nilai $\mathrm{C}_{\text {gabungan }}$ pada masing-masing perumahan dipengaruhi oleh tutupan lahan dan luas kawasan.

Tabel 5. Nilai $C_{\text {gabungan }}$ Tiap Perumahan

\begin{tabular}{ccc}
\hline \multirow{2}{*}{ Perumahan } & Luas & \\
\cline { 2 - 2 } $\mathbf{C}_{\text {gabungan }}$ \\
\hline Jamrud Residence & 31.450 & 0,6635 \\
Neo Batakan Permai & 424.633 & 0,6192 \\
GBR 6 & 19.500 & 0,6621 \\
\hline
\end{tabular}

\section{Estimasi Waktu Konsentrasi}

Waktu konsentrasi merupakan estimasi waktu air hujan yang mengalir hingga titik tertentu di hilir saluran. Perhitungan waktu konsentrasi digunakan dalam menentukan intensitas curah hujan, sehingga dilakukan perhitungan berdasarkan kondisi kawasan belum terbangun dengan persamaan Kerby (Ockert \& Jeff, 2014) dan kondisi kawasan terbangun dengan Persamaan Kirpich (Suripin, 2004) sebagai berikut.

a. Kondisi kawasan belum terbangun

$$
\mathrm{t}_{\mathrm{o}}=1,44 \times\left(n d \times \frac{L_{s}}{\sqrt{s}}\right)^{0,467}
$$

Dimana

$\mathrm{t}_{\mathrm{o}} \quad$ = Waktu yang diperlukan air mengalir di atas lahan menuju saluran (menit)

$\mathrm{L}_{\mathrm{s}} \quad=$ Panjang lintasan aliran di atas permukaan lahan $(\mathrm{m})$

$\mathrm{s} \quad=$ Kemiringan lahan $(\mathrm{m} / \mathrm{m})$

nd = Koefisien hambatan (digunakan 0,2 untuk permukaan sedikit berumput dan 0,8 untuk lahan dengan pohon-pohon berdaun)

b. Kondisi kawasan terbangun

$$
\begin{aligned}
& \mathrm{t}_{\mathrm{c}}=\left(\frac{0,87 \times L^{2}}{1.000 \times s}\right)^{0,385} \\
& \text { Dimana } \\
& \begin{array}{cl}
\mathrm{t}_{\mathrm{c}} \quad=\text { Waktu konsentrasi }(\mathrm{jam}) \\
\mathrm{L} \quad=\text { Panjang saluran utama }(\mathrm{km}) \\
\mathrm{s} \quad=\text { Kemiringan rata-rata saluran }(\mathrm{m} / \mathrm{m})
\end{array}
\end{aligned}
$$

dengan Persamaan Kerby dan Kirpich didapatkan tabel hasil perhitungan waktu konsentrasi pada Tabel 6 sebagai berikut: 
Tabel 6. Estimasi Waktu Konsentrasi

\begin{tabular}{cccc}
\hline Perumahan & \multirow{2}{*}{ nd } & $\mathbf{t}_{\mathbf{o}}$ & $\mathbf{t}_{\mathbf{c}}$ \\
\cline { 4 - 4 } & & jam & jam \\
\hline Jamrud Residence & 0,2 & 0,415 & 0,180 \\
Neo Batakan Permai & 0,8 & 0,641 & 0,140 \\
GBR 6 & 0,2 & 0,224 & 0,100 \\
\hline
\end{tabular}

Berdasarkan Tabel 6, hasil perhitungan waktu konsentrasi yang didapat berupa $t_{\mathrm{o}}$ untuk kondisi kawasan belum terbangun dan $t_{c}$ untuk kondisi kawasan terbangun, nilai-nilai ini kemudian akan digunakan dalam perhitungan intensitas curah hujan.

\section{Intensitas Curah Hujan}

Perhitungan curah hujan setiap waktu berdasarkan curah hujan harian dapat dilakukan dengan menggunakan persamaan Mononobe (Suripin, 2004) sebagai berikut.

$$
I=\frac{R_{24}}{24} \times\left(\frac{24}{t c}\right)^{\frac{2}{3}}
$$

Dimana

I = Intensitas curah hujan $(\mathrm{mm} / \mathrm{jam})$

tc $\quad=$ Waktu konsentrasi (jam)

$\mathrm{R}_{24}=$ Curah hujan maksimum dalam 24 jam (mm)

dengan persamaan mononobe didapatkan hasil perhitungan intensitas curah hujan yang disajikan pada Tabel 7. sebagai berikut.

Tabel 7. Intensitas Hujan

\begin{tabular}{|c|c|c|c|c|c|}
\hline \multirow{3}{*}{ Perumahan } & \multirow{3}{*}{ R24 mm } & \multicolumn{2}{|c|}{ Kondisi awal } & \multicolumn{2}{|c|}{ Kondisi terbangun } \\
\hline & & $\mathbf{t}_{\mathrm{c}}$ & $\mathbf{I}$ & $\mathbf{t}_{\mathrm{c}}$ & $\mathbf{I}$ \\
\hline & & jam & $\mathrm{mm} / \mathbf{j a m}$ & jam & mm/jam \\
\hline Jamrud Residence & 159,9481 & 0,415 & 99,661 & 0,18 & 173,123 \\
\hline Neo Batakan permai & 159,9481 & 0,641 & 74,575 & 0,14 & 205,663 \\
\hline GBR 6 & 159,9481 & 0,224 & 150,429 & 0,10 & 255,368 \\
\hline
\end{tabular}

Berdasarkan Tabel 7, dapat dilihat bahwa masing masing perumahan memiliki intensitas hujan yang berbeda-beda. Intensitas hujan yang dihasilkan pada kondisi awal lebih rendah dibandingkan pada kondisi terbangun karena dipengaruhi oleh perbedaan tutupan lahan dan waktu konsentrasi pengaliran $\left(\mathrm{t}_{\mathrm{c}}\right.$ ) pada tiap-tiap perumahan.

\section{Debit Banjir Rencana (Debit Limpasan)}

Penentuan laju aliran puncak atau debit banjir menurut Suripin (2004) berpacu pada ketersediaan data dilapangan dan digunakan metode umum yakni metode rasional sebagai berikut :

$\mathrm{Q}=0,278 \mathrm{C} . \mathrm{I} . \mathrm{A}$

Dimana

$\mathrm{Q}=$ Debit banjir maksimum $\left(\mathrm{m}^{3} / \mathrm{dtk}\right)$

$\mathrm{C}=$ Koefisien pengaliran

$\mathrm{I}=$ Intensitas hujan selama $\mathrm{t} \mathrm{jam}(\mathrm{mm} / \mathrm{jam})$

$\mathrm{A}=$ Luas Daerah Aliran Sungai $\left(\mathrm{km}^{2}\right)$ 
Persamaan 14 kemudian digunakan untuk menghitung debit banjir rencana. Hasil perhitungan debit banjir rencana pada kawasan belum terbangun disajikan pada Tabel 8 sebagai berikut.

Tabel 8. Debit Banjir Rencana Kawasan Belum Terbangun

\begin{tabular}{ccccc}
\hline \multirow{2}{*}{ Perumahan } & \multirow{2}{*}{ C awal } & $\mathbf{I}$ & $\mathbf{A}$ & $\mathbf{Q}$ awal \\
\cline { 3 - 5 } & & $\mathbf{m m} / \mathbf{j a m}$ & $\mathbf{k m}^{\mathbf{2}}$ & $\mathbf{m}^{\mathbf{3}} / \mathbf{d e t}$ \\
\hline Jamrud Residence & 0,4 & 99,661 & 0,03145 & 0,3485 \\
Neo Batakan permai & 0,5 & 74,575 & 0,42463 & 4,4017 \\
GBR 6 & 0,5 & 150,429 & 0,01950 & 0,4077 \\
\hline
\end{tabular}

Perhitungan debit banjir rencana juga dilakukan pada kawasan belum terbangun dengan Persamaan 14 pada tiap-tiap perumahan yang disajikan pada Tabel 9 sebagai berikut:

Tabel 9. Debit Banjir Rencana Kawasan Telah Terbangun

\begin{tabular}{ccccc}
\hline \multirow{2}{*}{ Perumahan } & C awal & $\mathbf{I}$ & $\mathbf{A}$ & $\mathbf{Q}$ awal \\
\cline { 3 - 5 } & & $\mathbf{m m} / \mathbf{j a m}$ & $\mathbf{k m}^{\mathbf{2}}$ & $\mathbf{~ m}^{\mathbf{3}} / \mathbf{d e t}$ \\
\hline Jamrud Residence & 0,6635 & 173,123 & 0,03145 & 1,0043 \\
Neo Batakan permai & 0,6192 & 205,663 & 0,42463 & 15,0329 \\
GBR 6 & 0,6621 & 255,368 & 0,01950 & 0,9166 \\
\hline
\end{tabular}

Berdasarkan hasil perhitungan, debit yang dihasilkan berbeda pada tiap-tiap perumahan dipengaruhi oleh nilai koefisien pengaliran, intensitas hujan serta luas kawasan. Semakin besar koefisien pengaliran (C) dan intensitas (I) maka berbanding lurus dengan debit yang dihasilkan.

\section{Analisis Zero Delta Q}

Analisis Zero delta $Q$ dilakukan untuk mengetahui selisih debit limpasan yang dihasilkan oleh kawasan perumahan setelah mengalami peralihan tutupan lahan. Persamaan yang digunakan pada analisis ini adalah sebagai berikut.

$\Delta \mathrm{Q}=\mathrm{Q}_{\text {terbangun }}-\mathrm{Q}_{\text {awal }}$

Dimana

$\Delta \mathrm{Q}=$ Selisih debit limpasan pada $\mathrm{Q}_{\text {terbangun }}$ dan $\mathrm{Q}_{\text {awal }}\left(\mathrm{m}^{3} / \mathrm{dtk}\right)$

$\mathrm{Q}_{\text {terbangun }}=$ Debit limpasan pada kondisi terbangun $\left(\mathrm{m}^{3} / \mathrm{dtk}\right)$

$\mathrm{Q}_{\text {awal }}=$ Debit limpasan pada kondisi sebelum terbangun $\left(\mathrm{m}^{3} / \mathrm{dtk}\right)$

dengan menggunakan persamaan 15, didapatkan hasil perhitungan pada Tabel 10 sebagai berikut:

Tabel 10. Zero delta $Q$

\begin{tabular}{cccc}
\hline Perumahan & $\mathbf{Q}_{\text {awal }}$ & $\mathbf{Q}_{\text {terbangun }}$ & Delta Q \\
\hline Perumahan & $\mathbf{m}^{\mathbf{3}} / \mathbf{d e t}$ & $\mathbf{m}^{\mathbf{3}} / \mathbf{d e t}$ & $\mathbf{m}^{\mathbf{3}} / \mathbf{d e t}$ \\
\hline Jamrud Residence & 0,3485 & 1,0043 & 0,6557 \\
Neo Batakan permai & 4,4017 & 15,0329 & 10,6312 \\
GBR 6 & 0,4077 & 0,9166 & 0,5088 \\
\hline
\end{tabular}

Berdasarkan Tabel 10, selisih yang didapat oleh tiap-tiap perumahan berbeda-beda yang dipengaruhi oleh koefisien aliran, intensitas dan luas kawasan. Besar nilai selisih debit limpasan tersebut merupakan debit maksimum yang akan dialirkan menuju kolam tampung selama durasi hujan tertentu. Besar nilai $\mathrm{Q}_{\text {awal }}$ tersebut merupakan debit maksimum yang dapat dialirkan menuju saluran outlet saat hujan berlangsung agar sesuai dengan prinsip Zero delta $Q$. 


\section{Analisis Hidrograf Kolam Tampung}

Analisis hidrograf kolam tampung dilakukan untuk mengetahui volume kumulatif kolam tampung. Perhitungan yang dilakukan dalam membuat unit hidrograf kolam tampung di paparkan dalam Astriawati (2017) sebagai berikut:

$$
\begin{array}{ll}
\text { Q inflow } & =\frac{t_{n}}{t c} \times Q \\
\text { Vol. inflow } & =\frac{1}{2} \times\left(t_{n}-t_{(n-1)}\right) \times\left(Q \text { inflow }_{n}+Q \text { inflow }_{(\mathrm{n}-1)}\right) \\
\text { Vol. kumulatif } & =\text { volume inflow }_{\mathrm{n}}+\text { volume kumulatif }(\mathrm{n}-1) \\
\text { Kedalaman } & =\frac{\text { Vol. kumulatif }}{\text { Luas kolam }} \\
& =\text { Debit limpasan yang masuk kedalam kolam tampung }\left(\mathrm{m}^{3} / \mathrm{dtk}\right) \\
\text { Qimana } & =\text { Waktu ke-n pada waktu konsentrasi }(\mathrm{jam}) \\
\mathrm{t}_{\mathrm{n}} \text { inflow } & =\text { Waktu konsentrasi }(\text { jam }) \\
\mathrm{t}_{\mathrm{c}} & =\text { Debit limpasan dari saluran menuju kolam }\left(\mathrm{m}^{3} / \mathrm{dtk}\right) \\
\mathrm{Q} & =\text { Volume debit limpasan yang masuk kedalam kolam tampung }\left(\mathrm{m}^{3}\right) \\
\text { Vol. inflow } & \ldots . .(18) \\
\text { Vol. kumulatif } & =\text { Akumulasi vol. inflow data ke-n dan vol. kumulatif data ke-(n-1) }\left(\mathrm{m}^{3}\right) \\
\text { Kedalaman } & =\text { Kedalaman kolam tampung }(\mathrm{m}) \\
\text { Luas kolam } & =\text { Luasan kolam tampung rencana }\left(\mathrm{m}^{2}\right)
\end{array}
$$

\section{Dimana}

dalam analisis ini, perhitungan durasi hujan efektif sesuai SNI 03-2453-2002 mengenai "Tata Cara Perencanaan Teknik Sumur Resapan Air Hujan Untuk Lahan Pekarangan” menggunakan persamaan sebagai berikut:

$$
\text { te }=\frac{0,9 \times R^{0,92}}{60}
$$

dimana :

te $\quad=$ Durasi hujan efektif (jam)

$\mathrm{R} \quad=$ Curah hujan periode ulang $(\mathrm{mm})$.

digunakan persamaan 16 hingga persamaan 20 dalam melakukan perhitungan unit hidrograf kolam tampung pada tiap-tiap perumahan sebagai berikut:

a. Perumahan Jamrud Residence

Perumahan Jamrud Residence memiliki hasil perhitungan hidrograf kolam tampung pada yang disajikan pada Tabel 11 sebagai berikut. 
Tabel 11. Kolam Tampung Perumahan Jamrud Residence

\begin{tabular}{|c|c|c|c|c|c|}
\hline tc & $Q$ inflow & $Q$ inflow & Vol. inflow & Vol. kum & dalaman \\
\hline jam & $\mathrm{m}^{3} / \mathrm{det}$ & $\mathrm{m}^{3} / \mathbf{j a m}$ & $\mathrm{m}^{3}$ & $\mathrm{~m}^{3}$ & $\mathbf{m}$ \\
\hline 0,000 & 0,000 & 0,000 & 0,000 & 0,000 & 0,000 \\
\hline 0,050 & 0,182 & 655,715 & 16,393 & 16,393 & 0,006 \\
\hline 0,070 & 0,255 & 918,001 & 15,737 & 32,130 & 0,012 \\
\hline 0,100 & 0,364 & 1311,430 & 33,441 & 65,572 & 0,025 \\
\hline 0,130 & 0,474 & 1704,859 & 45,244 & 110,816 & 0,043 \\
\hline 0,180 & 0,656 & 2360,575 & 101,636 & 212,452 & 0,082 \\
\hline 0,280 & 0,656 & 2360,575 & 236,057 & 448,509 & 0,173 \\
\hline 0,380 & 0,656 & 2360,575 & 236,057 & 684,567 & 0,263 \\
\hline 0,480 & 0,656 & 2360,575 & 236,057 & 920,624 & 0,354 \\
\hline 0,580 & 0,656 & 2360,575 & 236,057 & 1156,682 & 0,445 \\
\hline 0,680 & 0,656 & 2360,575 & 236,057 & 1392,739 & 0,536 \\
\hline 0,780 & 0,656 & 2360,575 & 236,057 & 1628,797 & 0,626 \\
\hline 0,880 & 0,656 & 2360,575 & 236,057 & 1864,854 & 0,717 \\
\hline 0,980 & 0,656 & 2360,575 & 236,057 & 2100,911 & 0,808 \\
\hline 1,080 & 0,656 & 2360,575 & 236,057 & 2336,969 & 0,899 \\
\hline 1,180 & 0,656 & 2360,575 & 236,057 & 2573,026 & 0,990 \\
\hline 1,280 & 0,656 & 2360,575 & 236,057 & 2809,084 & 1,080 \\
\hline 1,380 & 0,656 & 2360,575 & 236,057 & 3045,141 & 1,171 \\
\hline 1,480 & 0,656 & 2360,575 & 236,057 & 3281,199 & 1,262 \\
\hline 1,600 & 0,656 & 2360,575 & 283,269 & 3564,468 & 1,371 \\
\hline 1,650 & 0,474 & 1704,859 & 101,636 & 3666,104 & 1,410 \\
\hline 1,680 & 0,364 & 1311,430 & 45,244 & 3711,348 & 1,427 \\
\hline 1,710 & 0,255 & 918,001 & 33,441 & 3744,789 & 1,440 \\
\hline 1,730 & 0,182 & 655,715 & 15,737 & 3760,527 & 1,446 \\
\hline 1,780 & 0,000 & 0,000 & 16,393 & 3776,919 & 1,453 \\
\hline
\end{tabular}

berdasarkan Tabel 11, dapat diketahui volume kumulatif dari kolam tampung selama 1,78 jam adalah sebesar 3.776,919 $\mathrm{m}^{3}$ dengan kedalaman maksimum sebesar 1,453 m, untuk mendapatkan kedalaman kolam sebesar 1,453 m maka luas kolam tampung yang dibutuhkan sebesar $2600 \mathrm{~m}^{2}$. Berdasarkan hasil perhitungan pada Tabel 11, bentuk hidrograf kolam tampung yang dihasilkan disajikan pada Gambar 4 sebagai berikut:

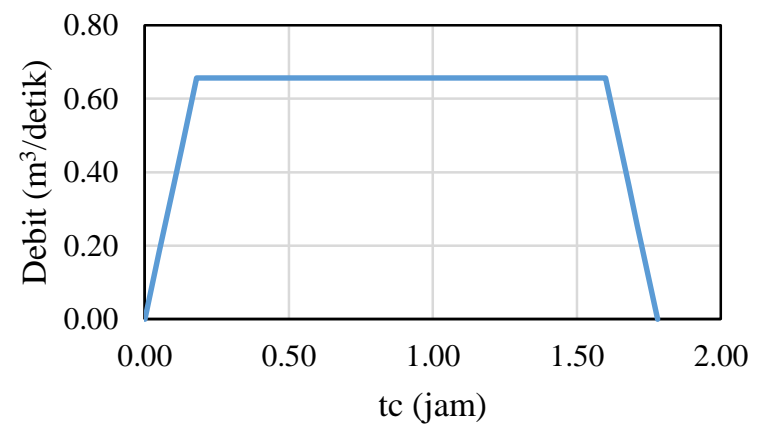


Gambar 4. Grafik hidrograf kolam tampung Perumahan Jamrud Residence

Berdasarkan Gambar 4, grafik hidrograf tersebut menunjukkan kenaikan debit selama 1,78 jam. Debit mengalami kenaikan hingga tc sebesar 0,18 jam kemudian bersifat konstan hingga tc mencapai 1,6 jam dan kemudian debit menurun karena durasi hujan telah selesai dimana debit yang masuk kedalam kolam tampung semakin kecil. Debit maksimum sebesar $0,6557 \mathrm{~m}^{3} /$ detik merupakan selisih debit limpasan yang dihasilkan oleh perumahan.

b. Permahan Neo Batakan Permai

Perumahan Neo Batakan Permai memiliki hasil perhitungan hidrograf kolam tampung pada yang disajikan pada Tabel 12 sebagai berikut:

Tabel 12. Kolam Tampung Perumahan Neo Batakan Permai

\begin{tabular}{cccccc}
\hline tc & Q inflow & Q inflow & Vol. inflow & Vol. kum & kedalaman \\
\hline jam & $\mathbf{m}^{\mathbf{3} / \mathbf{d e t}}$ & $\mathbf{m}^{\mathbf{3} / \mathbf{j a m}}$ & $\mathbf{m}^{\mathbf{3}}$ & $\mathbf{m}^{\mathbf{3}}$ & $\mathbf{m}$ \\
\hline 0,000 & 0,000 & 0,000 & 0,000 & 0,000 & 0,000 \\
0,050 & 3,797 & 13668,667 & 341,717 & 341,717 & 0,008 \\
0,080 & 6,075 & 21869,868 & 533,078 & 874,795 & 0,021 \\
0,110 & 8,353 & 30071,068 & 779,114 & 1653,909 & 0,039 \\
0,120 & 9,112 & 32804,801 & 314,379 & 1968,288 & 0,047 \\
0,130 & 9,872 & 35538,535 & 341,717 & 2310,005 & 0,055 \\
0,140 & 10,631 & 38272,268 & 369,054 & 2679,059 & 0,064 \\
0,240 & 10,631 & 38272,268 & 3827,227 & 6506,286 & 0,155 \\
0,340 & 10,631 & 38272,268 & 3827,227 & 10333,512 & 0,246 \\
0,440 & 10,631 & 38272,268 & 3827,227 & 14160,739 & 0,337 \\
0,540 & 10,631 & 38272,268 & 3827,227 & 17987,966 & 0,428 \\
0,640 & 10,631 & 38272,268 & 3827,227 & 21815,193 & 0,519 \\
0,740 & 10,631 & 38272,268 & 3827,227 & 25642,420 & 0,611 \\
0,840 & 10,631 & 38272,268 & 3827,227 & 29469,647 & 0,702 \\
0,940 & 10,631 & 38272,268 & 3827,227 & 33296,874 & 0,793 \\
1,040 & 10,631 & 38272,268 & 3827,227 & 37124,100 & 0,884 \\
1,140 & 10,631 & 38272,268 & 3827,227 & 40951,327 & 0,975 \\
1,240 & 10,631 & 38272,268 & 3827,227 & 44778,554 & 1,066 \\
1,340 & 10,631 & 38272,268 & 3827,227 & 48605,781 & 1,157 \\
1,440 & 10,631 & 38272,268 & 3827,227 & 52433,008 & 1,248 \\
1,600 & 10,631 & 38272,268 & 6123,563 & 58556,571 & 1,394 \\
1,610 & 9,872 & 35538,535 & 369,054 & 58925,625 & 1,403 \\
1,620 & 9,112 & 32804,801 & 341,717 & 59267,341 & 1,411 \\
1,630 & 8,353 & 30071,068 & 314,379 & 59581,721 & 1,419 \\
1,660 & 6,075 & 21869,868 & 779,114 & 60360,835 & 1,437 \\
1,690 & 3,797 & 13668,667 & 533,078 & 60893,913 & 1,450 \\
1,740 & 0,000 & 0,000 & 341,717 & 61235,629 & 1,458 \\
\hline & & & & & \\
\hline
\end{tabular}

Berdasarkan Tabel 12, dapat diketahui volume kumulatif dari kolam tampung selama 1,74 jam adalah sebesar 61.235,629 $\mathrm{m}^{3}$ dengan kedalaman maksimum sebesar 1,458 m, untuk mendapatkan kedalaman kolam sebesar 1,458 m maka luas kolam tampung yang dibutuhkan sebesar $42.000 \mathrm{~m}^{2}$. Berdasarkan hasil perhitungan pada tabel Tabel 12, bentuk hidrograf kolam tampung yang dihasilkan disajikan pada Gambar 5 sebagai berikut: 


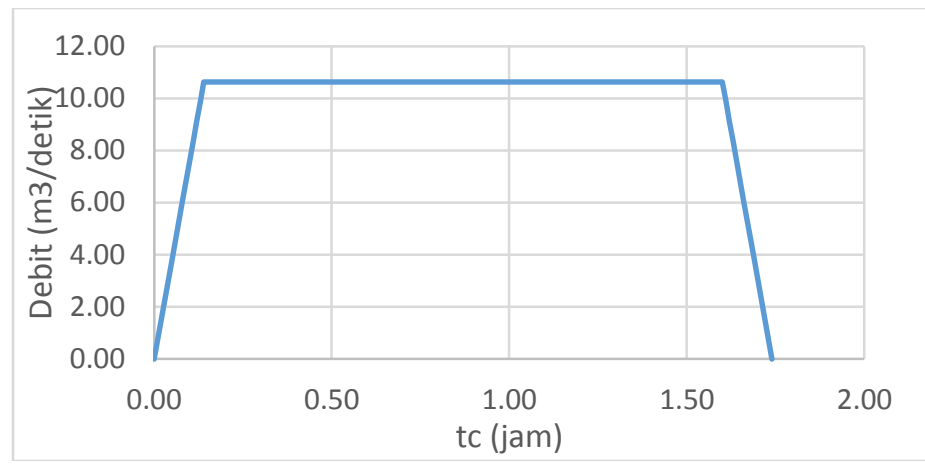

Gambar 5. Grafik hidrograf kolam tampung perumahan Neo Batakan Permai

Berdasarkan Gambar 5, grafik hidrograf tersebut menunjukkan kenaikan debit selama 1,74 jam. Debit mengalami kenaikan hingga tc sebesar 0,14 jam kemudian bersifat konstan hingga tc mencapai 1,6 jam dan kemudian debit menurun karena durasi hujan telah selesai dimana debit yang masuk kedalam kolam tampung semakin kecil. Debit maksimum sebesar 10,631 $\mathrm{m}^{3} /$ detik merupakan selisih debit limpasan yang dihasilkan oleh perumahan.

c. Perumahan GBR 6

Perumahan GBR 6 memiliki hasil perhitungan hidrograf kolam tampung pada yang disajikan pada Tabel 13 sebagai berikut:

Tabel 13. Kolam Tampung Perumahan GBR 6

\begin{tabular}{cccccc}
\hline tc & Q inflow & Q inflow & Vol. inflow & Vol. kum & kedalaman \\
\hline jam & $\mathbf{m}^{\mathbf{3} / \mathbf{d e t}}$ & $\mathbf{m}^{\mathbf{3} / \mathbf{j a m}}$ & $\mathbf{m}^{\mathbf{3}}$ & $\mathbf{m}^{\mathbf{3}}$ & $\mathbf{m}$ \\
\hline 0,000 & 0,000 & 0,000 & 0,000 & 0,000 & 0,000 \\
0,020 & 0,102 & 366,369 & 3,664 & 3,664 & 0,002 \\
0,050 & 0,254 & 915,921 & 19,234 & 22,898 & 0,011 \\
0,080 & 0,407 & 1465,474 & 35,721 & 58,619 & 0,029 \\
0,100 & 0,509 & 1831,843 & 32,973 & 91,592 & 0,046 \\
0,200 & 0,509 & 1831,843 & 183,184 & 274,776 & 0,137 \\
0,300 & 0,509 & 1831,843 & 183,184 & 457,961 & 0,229 \\
0,400 & 0,509 & 1831,843 & 183,184 & 641,145 & 0,321 \\
0,500 & 0,509 & 1831,843 & 183,184 & 824,329 & 0,412 \\
0,600 & 0,509 & 1831,843 & 183,184 & 1007,514 & 0,504 \\
0,700 & 0,509 & 1831,843 & 183,184 & 1190,698 & 0,595 \\
0,800 & 0,509 & 1831,843 & 183,184 & 1373,882 & 0,687 \\
0,900 & 0,509 & 1831,843 & 183,184 & 1557,066 & 0,779 \\
1,000 & 0,509 & 1831,843 & 183,184 & 1740,251 & 0,870 \\
1,100 & 0,509 & 1831,843 & 183,184 & 1923,435 & 0,962 \\
1,200 & 0,509 & 1831,843 & 183,184 & 2106,619 & 1,053 \\
1,300 & 0,509 & 1831,843 & 183,184 & 2289,804 & 1,145 \\
1,400 & 0,509 & 1831,843 & 183,184 & 2472,988 & 1,236 \\
1,500 & 0,509 & 1831,843 & 183,184 & 2656,172 & 1,328 \\
1,600 & 0,509 & 1831,843 & 183,184 & 2839,356 & 1,420 \\
1,620 & 0,407 & 1465,474 & 32,973 & 2872,330 & 1,436 \\
1,650 & 0,254 & 915,921 & 35,721 & 2908,050 & 1,454 \\
1,680 & 0,102 & 366,369 & 19,234 & 2927,285 & 1,464 \\
1,700 & 0,000 & 0,000 & 3,664 & 2930,949 & 1,465 \\
& & & & &
\end{tabular}


Berdasarkan Tabel 13, dapat diketahui volume kumulatif dari kolam tampung selama 1,70 jam adalah sebesar 2.930,949 $\mathrm{m}^{3}$ dengan kedalaman maksimum sebesar 1,465 m, untuk mendapatkan kedalaman kolam sebesar 1,465 m maka luas kolam tampung yang dibutuhkan sebesar $2.000 \mathrm{~m}^{2}$. Berdasarkan hasil perhitungan pada Tabel 13, bentuk hidrograf kolam tampung yang dihasilkan disajikan pada Gambar 6 sebagai berikut:

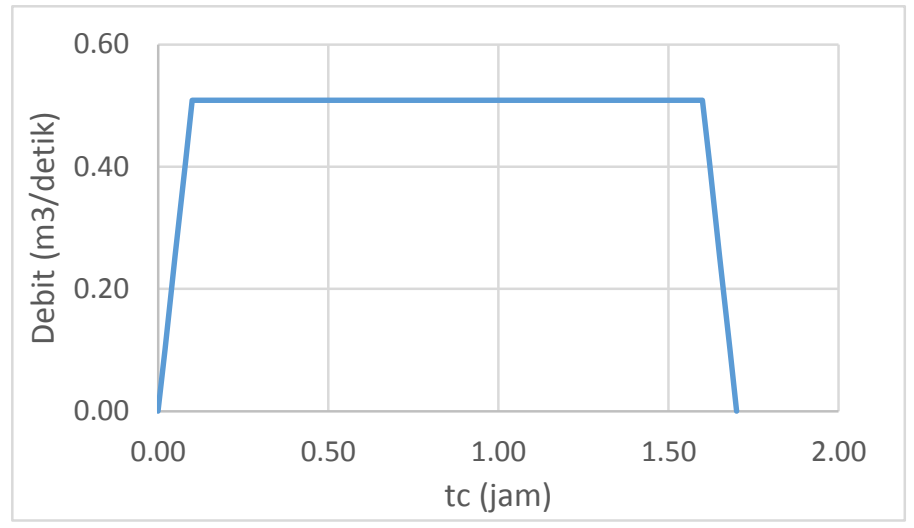

Gambar 6. Grafik hidrograf kolam tampung Perumahan GBR 6

Berdasarkan Gambar 6, grafik hidrograf tersebut menunjukkan kenaikan debit selama 1,70 jam. Debit mengalami kenaikan hingga tc sebesar 0,10 jam kemudian bersifat konstan hingga tc mencapai 1,6 jam dan kemudian debit menurun. Debit maksimum sebesar 0,5088 $\mathrm{m}^{3} /$ detik merupakan selisih debit limpasan yang dihasilkan oleh perumahan. Berdasarkan hasil perhitungan yang didapatkan, rekapitulasi volume dan kedalaman dari masing-masing perumahan disajikan pada Tabel 14 sebagai berikut:

Tabel 14. Rekapitulasi volume dan dimensi Kolam Tampung

\begin{tabular}{ccccccc}
\hline \multirow{2}{*}{ Perumahan } & $\begin{array}{c}\text { Volume Kolam } \\
\text { Tampung }\end{array}$ & Luas kolam Delta Q Kedalaman & $\begin{array}{c}\text { Kedalaman + } \\
\text { Tinge Jagaan } \\
\text { (f) }\end{array}$ & $\begin{array}{c}\text { Kedalaman } \\
\text { pakai }\end{array}$ \\
\cline { 2 - 7 } & $\mathbf{m}^{\mathbf{3}}$ & $\mathbf{m}^{\mathbf{2}}$ & $\mathbf{m}^{\mathbf{3}} / \mathbf{d e t}$ & $\mathbf{m}$ & $\mathbf{m}$ & $\mathbf{m}$ \\
\hline Jamrud Residence & $3.776,92$ & 2.600 & 0,656 & 1,45 & 1,95 & 2 \\
Neo Batakan Permai & $61.235,63$ & 42.000 & 10,631 & 1,46 & 1,96 & 2 \\
GBR 6 & $2.930,95$ & 2.000 & 0,509 & 1,47 & 1,97 & 2 \\
\hline
\end{tabular}

Berdasarkan Tabel 14, ditunjukkan masing-masing perumahan dengan volume kolam tampung yang dibutuhkan oleh perumahan untuk menampung selisih debit limpasan ( $\Delta \mathrm{Q})$. Nilai kedalaman (h) yang didapatkan kemudian ditambahkan dengan tinggi jagaan (f) sebesar 0,5 m sesuai Tata Cara Pembuatan Kolam Retensi dan Polder (Anonim, 2010).

\section{Analisis Rasio Luasan dan Pemodelan Persamaan Regresi Linier}

Luas kolam tampung yang didapatkan kemudian berdasarkan analisis hidrograf kolam tampung kemudian digunakan dalam menentukan rasio luasan kolam tampungan sebagai berikut:

Rasio luasan $=\frac{\text { Luas kolam tampung }}{\text { Luas kawasan }} \times 100 \%$

Dimana

Rasio luasan $=$ Rasio luas kolam tampung $(\%)$ 
Luas kolam tampung $\quad=$ Hasil perhitungan luas kolam tampung $\left(\mathrm{m}^{2}\right)$

Luas kawasan $\quad=$ Luas kawasan perumahan $\left(\mathrm{m}^{2}\right)$

digunakan Persamaan 21 sehingga didapatkan rasio luasan kolam tampung terhadap luas kawasan pada tiap-tiap perumahan yang disajikan pada Tabel 15 sebagai berikut:

Tabel 15. Rasio luasan kolam tampung

\begin{tabular}{ccccc}
\hline \multirow{2}{*}{ Perumahan } & Luas Kawasan & Luas Kolam Tampung & \multirow{2}{*}{ Rasio } & \multicolumn{2}{c}{ Total rasio } \\
\cline { 2 - 3 } & $\mathbf{m}^{\mathbf{2}}$ & $\mathbf{m}^{\mathbf{2}}$ & & $\boldsymbol{\%}$ \\
\hline Jamrud Residence & 31.450 & 2.600 & 0,08267 & 8,267 \\
Neo Batakan permai & 424.633 & 42.000 & 0,09891 & 9,891 \\
GBR 6 & 19.500 & 2.000 & 0,10256 & 10,256 \\
\hline
\end{tabular}

Berdasarkan Tabel 15, rasio luasan kolam tampung inilah yang dibutuhkan untuk menampung debit limpasan. Rasio luasan kolam tampung terhadap luas kawasan dipengaruhi oleh besarnya debit limpasan awal dan terbangun yang dihasilkan oleh perumahan. Pada perumahan jamrud residence rasionya lebih kecil dibandingkan Neo batakan permai sebab pengaruh selisih debit yang dihasilkan oleh perumahan Neo batakan permai lebih besar. Pada perumahan GBR 6, total rasio yang dihasilkan lebih tinggi dibanding perumahan yang lainnya yaitu 10,256\% sebab 95\% lahan didominasi bangunan dan jalan dan 5\% ruang terbuka hijau yang disediakan, hal ini berdampak pada nilai koefisien pengaliran perumahan yang mempengaruhi tingginya debit kawasan terbangun ( $\left.\mathrm{Q}_{\text {terbangun }}\right)$ yang berbanding lurus dengan selisih debit limpasan $(\Delta \mathrm{Q})$ dan rasio luasan kolam tampung yang dibutuhkan. Rasio luasan kolam tampung yang dibutuhkan dari tiap-tiap perumahan memiliki nilai yang lebih besar dibandingkan persentase minimal ketersediaan luasan bangunan pengendali yaitu sebesar $4 \%$ dari kawasan terbangun, persentase tersebut disyaratkan oleh peraturan daerah kota Balikpapan nomor 5 tahun 2013 tentang "Penyediaan Dan Penyerahan Prasarana, Sarana Dan Utilitas Pada Kawasan Perumahan". Persyaratan persentase tersebut ternyata belum cukup untuk menampung debit limpasan perumahan apabila prinsip Zero Delta Q Policy diimplementasikan dengan luaran berupa rasio luasan kolam tampung.

Rasio luasan kolam tampung terhadap luasan kawasan terbangun yang dihasilkan pada tiga perumahan kemudian dianalisis keterkaitannya. Analisis dilakukan untuk mengetahui keterkaitan antara luas kolam tampung terhadap luas kawasan perumahan dengan metode regresi linier. Analisis ini menghasilkan bentuk persamaan sederhana yang dilakukan menggunakan Microsoft Excel dengan data pada Tabel 16 sebagai berikut:

Tabel 16. Data luas kawasan dan luas kolam tampung

\begin{tabular}{lcc}
\hline \multirow{2}{*}{ mahan } & \multicolumn{2}{c}{ Luas Kawasan Luas Kolam Tampung } \\
\cline { 2 - 3 } & $\mathbf{m}^{\mathbf{2}}$ & $\mathbf{m}^{\mathbf{2}}$ \\
\hline Residence & 31.450 & 2.600 \\
kan Permai & 424.633 & 42.000 \\
3R 6 & 19.500 & 2.000 \\
\hline
\end{tabular}

berdasarkan data pada Tabel 16 di atas, data tersebut diinterpretasikan dengan diagram pencar dan didapatkan hasil regresi pada Gambar 7 sebagai berikut : 


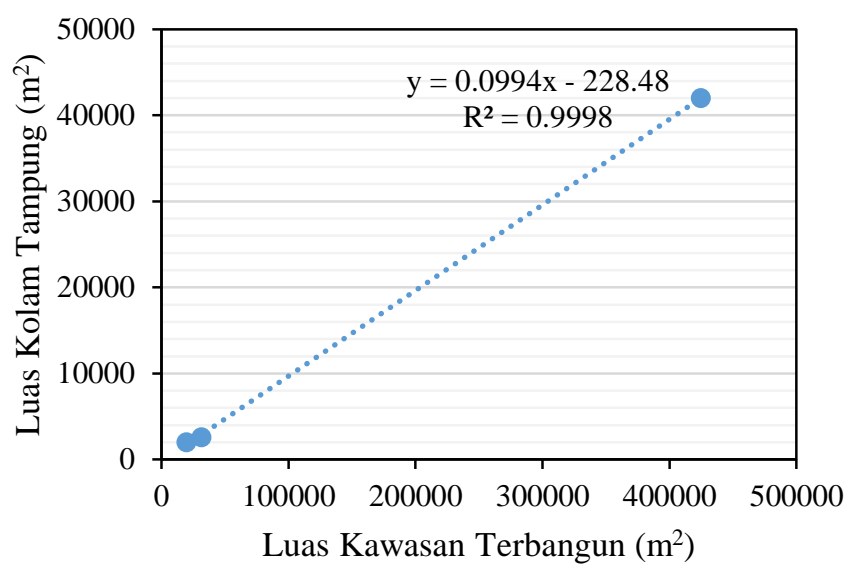

Gambar 7. Regresi linier luas kawasan terbangun terhadap luas kolam tampung

Berdasarkan Gambar 7, data yang diinterpretasikan dengan diagram pencar menghasilkan garis regresi dengan persamaan regresi linier yang didapatkan adalah:

$$
\mathrm{Y}=\left(0,0994 \times X_{1}\right)-228,48
$$

dimana :

$$
\begin{aligned}
& \mathrm{Y}=\text { Luas kolam tampung yang diprediksi }\left(\mathrm{m}^{2}\right) \\
& \mathrm{X}_{1}=\text { Luas kawasan perumahan }\left(\mathrm{m}^{2}\right)
\end{aligned}
$$

Berdasarkan persamaan regresi linier 4.1, disertai pula nilai $\mathrm{R}^{2}$ yang merupakan koefisien determinasi yaitu proporsi varian pada variabel yang menandakan tingkat keakuratan data variabel, akurasi semakin tinggi apabila bernilai mendekati 1 . Hasil $\mathrm{R}^{2}$ yang didapatkan pada Gambar 4.10 sebesar 0,9998 sehingga dapat dikatakan penggunaan persamaan linier 4.1 sebagai persamaan regresi linier sederhana akurat digunakan dalam memprediksi luas kolam tampung dengan variabel bebas berupa luas kawasan. Hasil persamaan regresi linier 4.1 memiliki nilai $\mathrm{R}^{2}$ mendekati 1 sehingga dikatakan akurat, namun persamaan tersebut hanya dapat memprediksi suatu luas kolam tampung terhadap luas kawasan. Prediksi terhadap luas kolam tampung akan lebih akurat apabila dilakukan analisis dengan menambah jumlah variabel bebas yang merupakan parameter-parameter penting lainnya dalam penentuan luasan kolam tampung. Analisis regresi yang dapat dilakukan dengan menggunakan lebih dari satu variabel bebas yaitu analisis regresi linier berganda. Analisis linier berganda dapat dilakukan dengan menambah jumlah variabel bebas berupa koefisien pengaliran, intensitas dan debit limpasan perumahan. Penambahan jumlah variabel bebas tersebut akan berpengaruh pada jumlah sampel minimal yang dibutuhkan yaitu sebesar jumlah variabel $(\mathrm{P})$ ditambah 2 atau $(\mathrm{P}+2)$. Berdasarkan kebutuhan sampel yang harus dipenuhi dalam analisis regresi linier berganda, jumlah sampel yang dimiliki dalam analisis ini hanya berjumlah tiga (3) sehingga tidak cukup untuk digunakan dalam menghasilkan persamaan regresi linier berganda dan alternatifnya adalah dengan membuat persamaan regresi linier sederhana dengan menggunakan satu (1) variabel yaitu luas kawasan. Apabila ingin didapatkan persamaan regresi linier berganda, maka dalam analisis selanjutnya perlu dilakukan penambahan terkait jumlah perumahan agar variasi variabel bebas dapat memenuhi jumlah variabel minimum yang disyaratkan.

\section{KESIMPULAN DAN SARAN}

Kesimpulan yang didapat berdasarkan hasil analisis terhadap perumahan Jamrud Residence, Neo Batakan Permai, dan GBR 6 adalah sebagai berikut: 
1. Debit limpasan yang dihasilkan saat kondisi kawasan belum terbangun $\left(\mathrm{Q}_{\mathrm{awal}}\right)$ pada perumahan Jamrud Residence sebesar 0,3485 $\mathrm{m}^{3} /$ detik, perumahan Neo Batakan Permai sebesar $4,4017 \mathrm{~m}^{3} /$ detik, dan perumahan GBR 6 sebesar $0,4077 \mathrm{~m}^{3} /$ detik.

2. Debit limpasan yang dihasilkan saat kondisi kawasan telah terbangun ( $\left.\mathrm{Q}_{\text {terbangun }}\right)$ pada perumahan Jamrud Residence sebesar 1,0043 $\mathrm{m}^{3} /$ detik, perumahan Neo Batakan Permai sebesar 15,0329 $\mathrm{m}^{3} /$ detik, dan perumahan GBR 6 sebesar 0,9166 m³/detik.

3. Analisis implementasi prinsip Zero Delta $Q$ policy menghasilkan rasio luasan kolam detensi yang dibutuhkan pada perumahan Jamrud Residence sebesar 8,267\%, perumahan Neo Batakan Permai sebesar 9,891\%, dan perumahan GBR 6 sebesar 10,256\% dari luas kawasan perumahan. Luasan kolam tampung sesuai dengan rasio pada masing masing perumahan memiliki pemodelan regresi linier yaitu $\mathrm{Y}=\left(0,0994 \times X_{1}\right)-228,48$ dengan koefisien determinasi $\left(\mathrm{R}^{2}\right)$ sebesar $0,9998 \approx 1$ sehingga dapat dikatakan penggunaan persamaan regresi linier sederhana akurat untuk digunakan.

Saran yang diperoleh berdasarkan hasil analisis guna pengembangan penelitian di masa yang akan datang antara lain pengembangan penelitian terkait jumlah sampel yang diambil masih belum dapat dikatakan mampu mewakili kondisi wilayah drainase Selatan. Selain itu, sampel yang digunakan tidak hanya perumahan saja akan tetapi seluruh bangunan komersial di wilayah studi.

\section{DAFTAR PUSTAKA}

Anonim. (2010). Tata Cara Pembuatan Kolam Retensi dan Polder. Satuan Kerja Pengembangan Penyehatan Lingkungan Permukiman, Direktorat Jenderal Cipta Karya, Departemen Pekerjaan Umum.

Astriawati. (2017). Perencanaan Sistem Drainase Apartemen Grand Dharma Husada Lagoon Surabaya. Tugas Akhir Sarjana. Departemen Teknik Sipil. Institut Teknologi Sepuluh November. Surabaya.

BMKG (2020). Curah Hujan Maksimum Harian Kota Balikpapan. Badan Meteorologi Klimatologi dan Geofisika. Balikpapan.

BPS (2019). Kota Balikpapan Dalam Angka. Badan Pusat Statistik. Balikpapan.

Maulana, M.A., Suprayitno, H. \& Soemitro, R.A.A. (2019). "River Infrastructure Preliminary Recognition". Journal of Infrastructure \& Facility Asset Management, 1(1), March 2019, $1-10$.

Ockert J. Gericke \& Jeff C. Smithers. (2014), "Review of Methods Used to Estimate Catchment Response Time for The Purpose of Peak Discharge Estimation". Hydrological Sciences Journal. Vol. 59, No. 11, pp:1935-1971, DOI: 10.1080/02626667.2013.866712

Bima Sakti Rahayu (2017). Site plan Perumahan Jamrud Residence. PT. Bima Sakti Rahayu. Balikpapan.

Kalimantan Pelita Nusantara (2020). Site plan Perumahan GBR 6. PT. Kalimantan Pelita Nusantara. Balikpapan.

Keysya Maju Jaya (2019). Site plan Perumahan Jamrud Residence. PT. Keysya Maju Jaya. Balikpapan.

PP 26/2008. Peraturan Pemerintah Republik Indonesia Nomor 26 Tahun 2008 Tentang Rencana Tata Ruang Wilayah Nasional.

SNI 03-2453-2002. SNI 03-2453-2002 tentang Tata Cara Perencanaan Sumur Resapan Air Hujan Untuk Lahan Pekarangan.

SNI 2415-2016. SNI 2415-2016 tentang Tata Cara Perhitungan Debit Banjir.

Suprayitno, H. \& Soemitro, R.A.A. (2018). "Preliminary Reflexion on Basic Principle of Infrastructure Asset Management". Jurnal Manajemen Aset Infrastruktur \& Fasilitas. Vol. 2, No. 1, Maret 2018, Hal.: 1 - 10. 
(e)ISSN 2615-1847 (p)ISSN 2615-1839

Jurnal Manajemen Aset Infrastruktur \& Fasilitas - Vol.5, No.1, Januari 2021

Suripin. (2004). Sistem Drainase Yang Berkelanjutan. Andi Offset. Yogyakarta. 